\title{
Chapter 12 \\ Knowledge Management \\ for Sustainability: The Spatial Dimension of Higher Education as an Opportunity for Land Management
}

\author{
Jens Schulz, Thomas Köhler, and Thomas Weith
}

\begin{abstract}
The production and dissemination of knowledge are seen as essential elements of sustainable land management (Salet 2014; Kaiser et al. 2016). Digitalisation creates a variety of opportunities for knowledge creation and communication. Knowledge cooperation and digitalisation for governance of land is a concept coined by the various and perhaps diverse interests of diverse stakeholders. In the era of digitalisation, new developments trigger further changes that may be of a challenging nature. However, digitalisation also offers innovative options for collaborative activity in land use, bringing together these diverse interests and eventually enabling new patterns of collaboration. The authors address principal patterns of collaboration in multi-stakeholder networks that have only recently been considered meaningful for research. Concepts from both domains-higher education and land management - are advantageously combined, allowing new interpretations of spatial and digital artefacts. Digitalisation is dramatically changing the knowledgerelated domain itself at the end of the 2010s. Besides encouraging new teaching and learning activities, new technologies also have an impact on knowledge spaces and on the institutional and personnel knowledge carriers established therein. However, the institutional and sectoral development of academic education practice has rarely been addressed in the context of higher education research. To illustrate the new way in which knowledge management is directed under such conditions, the authors briefly present digital networks from both sectors. Obviously, different layers of
\end{abstract}

\footnotetext{
J. Schulz

Institute of Knowledge Transfer and Digital Transformation, University of Applied Sciences, Technikumplatz 17, Mittweida, Germany

e-mail: Schulz3@hs-mittweida.de

T. Köhler $(\bowtie)$

Faculty of Education, TU Dresden, Weberplatz 5, Dresden, Germany

e-mail: Thomas.Koehler@tu-dresden.de

T. Weith

Institut für Umweltwissenschaften und Geographie, University of Potsdam, Campus-Golm, Karl-Liebknecht-Str. 24-25, Potsdam 14476, Germany

e-mail: Thomas.Weith@zalf.de
}

Working Group "Co-Design of Change and Innovation", Leibniz Centre for Agricultural Landscape Research, Eberswalder Str. 84, Müncheberg 15374, Germany

(C) The Author(s) 2021

T. Weith et al. (eds.), Sustainable Land Management in a European Context,

Human-Environment Interactions 8, https://doi.org/10.1007/978-3-030-50841-8_12 
stakeholders (state ministries and other authorities; higher education institutions and their sub-units, and other societal actors, etc.) need to collaborate in order to define and run the processes prevailing in and for higher education. How do these spatially distributed institutions interrelate in order to co-design the higher education landscape across an entire federal state? Which structures and processes are applied in co-design practices? Consequently, this paper outlines these developments, and combines knowledge economics, educational geography and educational science approaches in the context of higher education research.

Keywords Land management · Higher education · Digitalisation · Knowledge management $\cdot$ Sustainability

\subsection{Introduction}

The production of new knowledge and the dissemination of knowledge are seen as essential elements of sustainable land management (Salet 2014; Kaiser et al. 2016). Digitalisation creates a variety of opportunities for knowledge creation and communication. Until now, new methods have mainly been discussed and implemented in research projects and programmes. But how can knowledge creation be combined with processes in the higher education system in the context of digitalisation? And what opportunities exist for sustainable land use and spatial development under these circumstances? Besides developing single curricula, the following chapter will reflect on the spatial conceptual models behind current practices in higher education, enabling the authors to discuss alternatives for the future in this field of knowledge creation and dissemination.

Digital media, as a core component and important output of digitalisation processes, differs significantly from conventional knowledge media, given that it emphasises cooperative action-whether in the form of human-machine interaction or as interpersonal mediated communication (Köhler 2006). Friedrich W. Hesse, the founding director of the Leibniz Institute for Knowledge Media in Tübingen, pointed out: "Through digital resources, a knowledge space is changing and knowledge work is changing" (Hesse 2017). Although in this case knowledge space stands for a mathematical structure that reflects the results of the learning process, the knowledge work clearly refers to a spatially effective size in the geographical understanding, since production, storage and transfer of knowledge require appropriate infrastructures or people.

Scientific discourse in spatial sciences (e.g. Kaiser et al. 2017) outlines how relevant opportunities for collaborative activity in land use occur, possibly bringing together diverse interests and eventually enabling new patterns of collaboration to be detected. Has research been able to identify principal structures of collaborative interrelations in multi-stakeholder networks? And how will governance models be affected? This aspect is especially relevant in the European context, where equal 
living conditions are quite often an underlying political target of spatial development, and where spatial justice is often seen as a basis for the distribution of both infrastructure and subsidies. Addressing these rather complex questions, the authors seek to open up the agenda for a theoretical discourse and subsequently an empirical discourse, to be documented in the present chapter. A possibly innovative momentum will be developed from the combination of theoretical domains-knowledge cooperation and digitalisation in higher education for the governance of land, which have so far been rather independent.

An interdisciplinary analysis of the technological, social, (organisation) didactic and policy-related challenges is required so as not only to accompany, but also to shape developments in the concrete case. The link between digitalisation and the concept of space is addressed by introducing the concept of knowledge as an interface. Future research in digitised knowledge cooperation will be linked with research and explanatory approaches of higher education research and research on informational land use, applying aspects such as organisational research, the knowledge economy and educational geography.

First, the authors provide a brief introduction to the status quo of the two chosen domains - research on knowledge in land management (related to information and communication, and relevant technologies) and higher education research (focusing on e-learning, organisational development and digitalisation).

\subsubsection{Generating and Disseminating Knowledge for Sustainable Land Use}

Knowledge can generally be understood as the conscious processing and adoption of information. In the same vein, knowledge is also defined as the process of purposeful connection of information (North 2011: 36f). Change processes, also in land use, are characterised by making individual knowledge accessible to the actors involved (Nonaka and Takeuchi 1995). New knowledge is generated by the cyclical repetition of the internalisation of information and processing into knowledge (learning), and its externalisation (communication). Learning, feedback and communication thus serve the purpose of knowledge generation and knowledge dissemination, supported by the moderation of intermediaries. In recent years, considerable progress has been made with regard to the development and availability of codified knowledge stocks and new knowledge generation processes by digitalisation.

The handling of real sustainability problems such as challenges in land use depends on the production and dissemination of new knowledge produced in this way. This is often developed in transdisciplinary settings in a co-design approach. Such practice enables the integration of different forms of knowledge, resulting, in particular, from the diversity of practitioners involved in the research process. As a result, contributions to the solution of complex societal challenges are grouped around problems, rather than scientific disciplines (Pohl 2014). 
With sustainability research in mind, several authors stress the need for this kind of research; the current lack of knowledge; and new methods of knowledge management (e.g. Miller et al. 2014: 244; Kajikawa et al. 2014). For several years, research efforts have focused more on producing the knowledge required to understand the challenges. Until now, the 'quality and validity of knowledge systems in the context of sustainability research' have been a major challenge (Cornell et al. 2013) within knowledge systems (ibid.: 61).

Scientific debates in this context are accompanied by science policy debates and political discourses. The Sustainable Development Goals (SDGs) document is an important political statement in this context. Knowledge management is addressed in three SDG objectives (Goal 4: quality education; Goal 16: peace, justice and strong institutions; and Goal 17: partnerships for the goals). It is simultaneously linked to education and lifelong learning. An explicit reference to digitalisation is also mentioned for the first time in the SDGs. Besides being relevant to many sustainability goals, digitalisation is explicitly addressed in sub-goal 9c (Industry, Innovation and Infrastructure): "To substantially improve access to information and communication technology and to ensure universal and affordable access to the Internet in at least developed countries by 2020". ${ }^{1}$ The accompanying "Future Earth" research process is of great importance for the development and implementation of the SDGs. This global network focuses on the development and dissemination of new knowledge and the exchange of knowledge (www.futureearth.org). One of the network's explicit goals is to support the transformation towards sustainability. The associated research agenda states that this also requires a new form of knowledge generation across disciplinary boundaries, together with social partners.

While knowledge is a precondition for action, co-designed processes for the generation and management of knowledge are considered to be core elements for sustainable spatial development and land use (Salet 2014). Davoudi (2015) grasps the knowledge-action relationship in a manner that defines "planning as practice of knowing". In this context, knowledge is quite often based on a variety of experiences in practice, embedded in social networks and organisational structures (Zimmermann 2010: 118). In this way, knowledge production and dissemination is not a single task to be addressed by several experts, but is accompanied by regional and local knowledge from a variety of actors.

The processes must be complemented by actors who manage the processes of knowledge cooperation or learning. This task often involves moderating, comparable to the tasks of facilitators and, in some cases, mediating actors (cf. Stützer et al. 2013). Moderation implements the "cohesion function", i.e. guiding group work, keeping the group together, introducing rules, overseeing, and harmonising group members, as well as the "locomotion function", i.e. setting group work in motion, and ensuring effective and focused working methods (Ziegler 1993). On this basis, the mediating actor fulfils two functions: those of discussion leader and consultant. Another concept of facilitated interaction is that of intermediaries, which is close to the method of moderation. Millar and Choi (2003) define knowledge intermediaries

\footnotetext{
${ }^{1}$ https://www.un.org/development/desa/disabilities/envision2030.html
} 
as organisations that "facilitate a recipient's measurement of the intangible value of knowledge received" (ibid.: 269). One function of the knowledge intermediary is to provide firms and/or knowledge producers with technology and knowledge transfer processes in the context of regional innovation systems (Parker and Hine 2013). The findings about intermediaries provide helpful information for determining who is responsible for knowledge management. Recent approaches often refer to the changing role of knowledge professionals. This role may even disappear completely, such as in the case where the question is asked: "Does a class need a teacher?" (Köhler and Kahnwald 2005). Indeed, greater emphasis is placed on sharing interests in practice than on following a predefined curriculum (Kahnwald and Köhler 2007).

Regarding the transfer of knowledge, the use of a unidirectional or one-way transfer from knowledge producers to knowledge consumers (also called "mode 1 ") to deal with information and knowledge flows cannot adequately reflect the challenges of a decision-making process or of a planning support process in a complex multi-stakeholder environment. This mode of science-policy interaction can be described as the "science push" and/or the "demand pull" model (Dilling and Lemos 2011). The new focus of knowledge transfer activities also considers the communication, translation and mediation of knowledge (Cash et al. 2003). Gibbons et al. (1994) call this focus "mode 2 knowledge" in the context of transdisciplinary research. The experiences of transdisciplinary research, primarily characterised by the cooperation of scientists and practitioner stakeholders, confirm the barriers and disadvantages of "mode-1" versus "mode-2" knowledge production (cf. Hirsch Hadorn et al. 2008). Thus, assembling different stakeholders in various groups throughout the planning process is one of the crucial conditions for a sustainable decision-making process and a key pillar of the currently consolidating concept of transdisciplinarity (Gibbons et al. 1994; Pohl 2011; Opdam et al. 2015). From this point of view, mutual collaboration of the stakeholders concerned is required in order to support knowledge production, transfer and implementation - this is the idea behind the concept of the co-production of knowledge (Pohl et al. 2010; Enengel et al. 2012). Lemos and Morehouse (2005) argue that an iterative and interactive model for the co-production of science and policy requires interdisciplinarity, stakeholder participation and the production of usable knowledge, which can be incorporated into all stakeholders' decision-making processes. They also acknowledge in this context that usable knowledge "not only must be tailored to fit stakeholders' needs and uses, but must also be made accessible to those users" (ibid.: 62).

Usability, accessibility and transferability depend in many ways on "producers" and "producing processes". Perspectives on challenges and problems define the starting points of agenda processes. Co-design processes are essential, followed by the co-production of knowledge, accompanied by exchange and interaction (Mauser et al. 2013: 427). In consequence, one of the most important questions at the beginning of the process is whom to define as an important actor. In addition, actor networks and organisational units are highly relevant, because single actors are embedded, 
and also develop and share knowledge within their organisations. In consequence, the use of transdisciplinary approaches also means exchanging knowledge between organisations that start bargaining processes, and developing framing narratives in institutional settings. This will raise awareness beyond projects to whole systems such as higher education.

\subsubsection{New Ways of Knowledge Generation, Dissemination and Management: Higher Education Research with a Focus on E-Learning, Organisational Development and Digitalisation}

The institutional and sectoral development of academic education practice has rarely been addressed in the context of higher education research. While a major interest of education research is linked to understanding specific didactic effects, the interdisciplinary approach is crucial to cope with the complexity of organisational relationships and the institutional contexts in which the digitalisation of higher education takes place. Decision-making and the forecasting of such processes appear to be challenging in this sector. Dimensions to be covered include the following aspects or areas of research and practice:

- Structures and actors,

- Administration, governance and organisational development,

- Didactics and competence development, and

- Educational technologies and technical infrastructures.

The professions represented in higher education development committees should ideally reflect these four points. But what does this mean for knowledge practices in a completely digitised knowledge society with more and more immaterial goods? Indeed, it is also possible to recruit expertise at any time and disseminate it through various exchange formats within research or practice communities, or to elaborate such expertise in projects via digital media and relevant formats of collaboration. As a result, higher education research must consider society in general in order to gain an appropriate understanding of how knowledge is generated, shared and transferred. Extending such understanding would also require ideas about spatial organisation beyond the embedding of this knowledge-related practice in the physical space of educational buildings. 


\subsection{Digitalisation of Higher Education}

\subsubsection{Classification into Megatrends of the Twenty-First Century}

Two thematic areas are particularly striking when analysing current global megatrends: there are demographic and social scientific considerations as well as economic interpretations. In many cases, however, the boundaries between these domains are fluid because there are interactions and links between them. In addition, each of these megatrends can be accompanied by current developments in the field of education, which require detailed analysis in terms of digitalisation processes. Interesting connections can be established, particularly for universities (see Table 12.1).

The challenges presented here are only examples, and are not consistent in the list. They provide an overview in the sense of impetus, seeking to reveal the connections that are currently important to the education system. With regard to conclusions and consequences, the table shows how important it is to combine new forms of knowledge management with higher education. This goes hand in hand with the changing framework conditions, particularly in higher education, from a greater focus on the labour market, to digitalisation, globalisation and new forms of governance.

Table 12.1 Global megatrends (Stang and Eigenbrodt 2014: 233ff) and exemplary challenges for higher education in the context of German approaches

\begin{tabular}{|c|c|}
\hline Global megatrend & Exemplary challenges for higher education \\
\hline Demographic change & Lifelong learning \\
\hline Individualisation of the mass market & $\begin{array}{l}\text { New (multi-site) study and learning } \\
\text { opportunities }\end{array}$ \\
\hline Social fragmentation & $\begin{array}{l}\text { "Ascension through education"; "open access } \\
\text { universities" }\end{array}$ \\
\hline Urbanisation & Competition between university locations \\
\hline Mobility & $\begin{array}{l}\text { Online learning/studying versus "global } \\
\text { villages"a }\end{array}$ \\
\hline Digitalisation of all areas of life & $\begin{array}{l}\text { Skills, competences, habits and preferences of } \\
\text { teachers and students }\end{array}$ \\
\hline $\begin{array}{l}\text { Automation and flexibility in collaborative } \\
\text { working environments }\end{array}$ & $\begin{array}{l}\text { Learning analytics; artificial intelligence; big } \\
\text { data }\end{array}$ \\
\hline Knowledge-based economy & $\begin{array}{l}\text { Knowledge transfer in knowledge regions and } \\
\text { globally; new requirements for education and } \\
\text { training }\end{array}$ \\
\hline Significance of education & $\begin{array}{l}\text { Weakening the prohibition of cooperation under } \\
\text { Article } 30 \text { of the German Constitution; "Quality } \\
\text { Pact Teaching" of the BMBF }\end{array}$ \\
\hline
\end{tabular}

${ }^{a}$ This term, first introduced by Marshall McLuhan in 1962, is a media-theoretical description of the world that grows together through electronic networking (in the sense of electronic interdependence) (McLuhan 2008) 


\subsubsection{Digital Media and the Resulting Changes in Higher Education Teaching and Learning}

The digitalisation of (higher) education unfortunately remains an issue that fails to create an optimistic and positive image of the future among the public (Schulz 2018). This is certainly not unfounded and is sometimes important; but as a societal cross-cutting task, there should at least be a vision for action in the future. However, digital transformation in education is particularly evident when comparing courses requiring presence to online courses. The example of "seminar versus webinar" shows the extent to which change is generally understood. In universities, students often sit in rows facing the lecturer, with a notebook or tablet on their desks in front of them, while students interact with teachers or each other, depending on the nature of the course. The lecturer uses a digital projector to show PowerPoint slides. The difference to face-to-face courses 20 years ago is astounding: notebooks and tablets take the place of books and paper; PowerPoint presentations have ousted the blackboard. Features may, of course, depend on the teacher and the subject culture, but most courses, whether seminars or lectures, now take place in such a format. Indeed, recent forecasting using scenario and Delphi techniques suggests that there will no longer be any pure offline educational situations by 2030 (Köhler et al. 2018, 2019).

Webinars are purely online seminars. They dissolve the physical space of the course, as both lecturers and students can participate from anywhere. Citizens of the "global village" come together in a virtual space; link up with knowledge of others in real time; generate their own knowledge; and finally share that knowledge with others. On closer inspection, however, most offers are a 1:1 transfer of the seminar concept to a non-physical space: the lecturer determines the degree of interaction by assigning rights; students sit (or lie) in front of a computer with an image transfer of the lecturer and the PowerPoint slides, and note important information in virtual and/or physical exercise books. Although there has been significant progress with digitally enhanced courses in terms of participation in educational processes, the opportunities associated with digital technologies are rarely fully exploited.

As mentioned above, digital teaching and learning technologies also open up new opportunities for imparting knowledge and learning material. Media didactics differentiate between "traditional" and "new" media formats. Traditional media formats are understood to be mainly analogue texts, images, graphics, presentations, films, videos and audio files. In this case, information and communication technologies are used for unidirectional performance or instruction. Newer mediation formats allow students to apply knowledge, obtain feedback or interact with fellow students in a more connectivist, co-constructionist way. As a consequence, the spatial distance is no longer decisive, but online access and interaction possibilities are 
Excursus: Online interactions include video, audio and chat conferences, and digitally based forums, as well as digital simulations and business games, etests, common media products, wikis and blogs. Riedel et al. (2017) found in a survey among all lecturers at universities in Saxony that the use of traditional media formats clearly predominates. More than 98 per cent of the respondents stated that they used texts, presentations, graphics and images in digital form, almost 77 per cent used films, videos and audio files. In contrast, the new media formats mentioned, which encourage interaction, are only part of the teaching portfolio for about a third of the teaching staff (e.g. forums: $37.3 \%$; e-tests: $24.8 \%$ ).

At first glance, the primary media-didactic question about the use of different media formats in teaching seems to have little spatial impact in the geographical sense. However, if one includes social and communicative aspects of virtual cooperation, changes in the room can be expected. Regardless of an increase in the degree of use of such new media formats, devaluation, or at least a reclassification of currently used learning spaces, may occur. In contrast, new learning spaces are being created in places that are not yet intended for such use. Examples include spaces used while commuting to university, and student services cafés.

\subsection{Spatial Dimensions: Informal Spaces and New Learning Worlds in Adult and Continuing Education}

\subsubsection{Governmental Argumentation in Favour of Digital Continuous Education}

Official education policy, however, seems to consider online elements of education as being rather relevant for postgraduate education. Yet educational processes also take place outside of schools and universities. In adult and continuing education in particular, far-reaching developments can be observed, and are expected in the years ahead. The Federal Ministry for Economic Affairs and Energy (BMWi), for example, helps companies to digitise their business processes or sales channels, or to develop personnel by way of digitised training and e-learning. The ministry argues for the latter as follows: "If employees can use digital media for further training, companies and employees benefit:

- A large number of employees can be continuously trained.

- Further training can take place regardless of time and location.

- Standardised content can be prepared interactively, quickly and in a way that promotes learning.

- Compulsory training can be demonstrated more effectively (compliance). 
- Learning groups can be virtually networked across locations.

- Customer training (product training) can take place digitally.

- Costs can be saved by, e.g. shortening learning times or by eliminating travel costs" (BMWi 2016: 24).

In the context of equal spatial development through digitalisation in education, the key words in this list are "location and time independent", "networked across locations ..." and "no travel expenses". The interpretation can go so far that digitalised educational offers mean that traders and their employees in peripheral, rural areas no longer have to fear location disadvantages with regard to further and advanced training. All the necessary events and training courses, including the product training mentioned, would be ubiquitously available, contributing to equal opportunities between differently characterised areas and regions.

\subsubsection{Changes in Organisational Learning and Communication Behaviour}

What conclusions can be drawn concerning the domain of educational governance? On the one hand, political aims and targets stress the desire for equal living conditions and fair opportunities for development. In recent years, discourses about new modes of governance have stressed development policies away from simply state-driven hierarchical systems towards integrative approaches, adopting the variety of actors' positions and network organisation. The organisational and regulatory system coordinates interaction between state and non-state actors of all kinds. "It is ... about how we establish goals, how we define rules for reaching the defined goals, and finally how we control outcomes following from the use of these rules" (Vatn 2005). There will be fewer conflicts, and common goals will be achieved.

On the other hand, there are still differences between rural areas and urban regions concerning the use and acceptance of digital resources. ${ }^{2}$ An additional aspect that has only been so far been given little consideration is the potential different patterns of information culture between urban versus rural regions and their inhabitants. Indeed, the research literature shows that this topic of organisational learning and communication behaviour is a relatively undiscovered territory when it comes to the question of implementing information and communications technologies (ICT).

Another contradictory observation in relation to the far-reaching potential of technologies is the observation that administrative advantages are often serve an easy entry point of ICT into any domain, before applications arrive in the sectoral practices. For example, in education learning was mainly adopting administrative moments before educational practice started to reform (Erber et al. 2004). However, recent studies on ICT-based management procedures in general education (Bergner ${ }^{2} \mathrm{https}: / / \mathrm{www}$. spiegel.de/netzwelt/web/breitband-ausbau-auf-dem-land-hinkt-hinterher-a-130
2174.html 
2019) confirm that virtually no schools in Germany apply enterprise resource planning (ERP) technologies, which are commonplace in industry, not even in a simple way.

As information and communication devices, and related applications, increasingly penetrate everyday private and professional life, behaviours also change. However, learning can also take place in informal arrangements, whilst formal settings can be configured and enriched in very different ways to one or two decades ago. This new learning behaviour is characterised by:

- Interactivity,

- Anonymity,

- Individualisation,

- Hyper mediality,

- Topicality and

- Globality (Semar 2014: 12f).

This has been described briefly in Sect. 12.2. But a second change can already be observed in addition to "new learning", because the new technical conditions are able to turn almost all learners into lecturers (whereby this term should be used with caution, since it is usually associated with a formally proven teaching qualification). Any individual who believes that they have specific knowledge or have solved a practical problem can create an explanatory video with the simplest of means; upload it onto an appropriate internet platform; and hope that interested parties will find it. It instantaneously becomes an educational offer, even though the material may have not been elaborated with didactics in mind, and can be integrated into formal learning arrangements without any barriers. A seventh point "Knowledge transfer through production and distribution" can therefore be added to the above description of learning behaviour, whereby "Changed communication behaviour during the learning process" would be a more precise description in many cases.

\subsubsection{Economic Versus Educational Perspectives: A Sample Case}

To illustrate this development in the educational versus economic domain, the authors decided to present a sample case in the context of one of the largest German university associations for digital learning, the Education Portal Saxony (Bildungsportal Sachsen).The goal of this collaborative project, established only in 2019-2020, focusing on "virtual teaching cooperation", is to pilot cross-university teaching processes, taking into account the didactics of collaborative teaching and learning, ideally in a specialist domain and possibly between different university types. It also seeks to develop solutions for cooperation with international partners. Furthermore, the project seeks to promote the subject-independent (interdisciplinary) qualification of educational staff to strengthen the effectiveness of the self-regulation of students 
in online or blended learning scenarios in such open collaborative networks, for example by acquiring online tutoring skills and abilities. Finally, individual Saxonywide preliminary courses and online self-assessment tests are supported with the use and creation of open educational resources (OER). ${ }^{3}$

\subsection{Interactions of Space and Education in the Context of Digitalisation}

\subsubsection{The Spatial Dimension}

Digitalization goes far beyond purely economic applications, and therefore illustrates the specific relevance for spatial and land-related developments. The link between digitalisation and the concept of space is addressed at this point by introducing the concept of knowledge as an interface. An outline has already been given of how the acquisition of knowledge using new information and communication tools will change, and continue to change. The possibilities of the location-independent and time-independent design of educational processes reveal that digitalisation is not a point-source event, but one that takes place in an area. The concept of knowledge in its spatial dimension is analysed as the central point of the discourse, since all actors become effective as part of their complex spatial environments.

New dynamics subsequently arise following the detachment of the physical connection of knowledge and information towards individuals. The concept of knowledge regions, which, when understood traditionally, was based on geographical, almost demarcated areas and easily comprehensible actor interactions, needs to be readjusted in the light of digitalisation. It can be assumed that there will be developments towards differentiated knowledge networks or global knowledge clusters, i.e. the spatial dimension will decline in favour of the knowledge economy, meaning that planning processes for any education domain will take place in new spatial thinking patterns.

\subsubsection{Relevant Knowledge Economics and Educational Geographic Assumptions}

It makes sense to use other relevant knowledge-economic and educational geographic assumptions to understand the spatial dimension described above. Initially, these must be interpreted as being detached from parallel digitalisation. Yet it is obvious

\footnotetext{
${ }^{3}$ https://bildungsportal.sachsen.de/portal/parentpage/projekte/hochschulvorhaben/projekte-20192020/virtuelle-lehrkooperationen
} 
that a process is already taking place on a national or global scale, receiving new dynamics through digitalisation, which will certainly be preserved.

The first assumption relates to the production and (re)use of knowledge. Innovation processes are driven accordingly by different knowledge bases (Kujath and Peiker 2014), i.e. by networking knowledge producers in specialist communities or the ubiquity of classic and new knowledge media. The emergence of innovations is basically conceivable anytime, anywhere. In these traditional knowledge networks, places and regions, institutions and organisations are interconnected, forming the common basis for processes that can then culminate in a result.

This is followed by a second assumption, which states that competition and cooperation within a common theme are not mutually exclusive, and take place regionally, supra-regionally and globally. There are fixed interaction mechanisms between actors, which may be both different and of the same institutional type, e.g.

- Colleges and universities, R\&D institutions,

- Primary and secondary educational institutions,

- Actors in knowledge-intensive regional development,

- The population as a carrier of knowledge-related identity, and

- Established and newly founded knowledge-intensive companies.

This is likely to have the greatest possible impact on each individual network member (Fromhold-Eisebith 2010). In addition to this concept, Kujath (2010) offers a third assumption for the above-mentioned interaction processes, which are also not only a social element, but primarily a transfer of knowledge and know-how: specialised transaction service providers support the transfer of knowledge between people, network nodes, knowledge regions and organisations. These are groups of actors who collect, store and process knowledge, and do business with it. Information and knowledge have, in fact, become a global commodity. However, the economic pursuit of profit need not necessarily be in the foreground, because not only international conferences or-with the leap towards digitalisation-operators of digital research and open access, but also publication networks may act as transfer service providers. Such a process has been described by Köhler and Schilde (2003) for higher education institutions by adopting the information broker concept from industry. The main finding would be moving away from thinking about territories and places, to inter-relational spaces. This would have to be reconsidered in the higher education system, in the sense of theoretical analysis.

\subsubsection{Exemplary Developments in the Context of Research on Knowledge Networks in Land Use in Germany}

One example of web-based knowledge platforms is the "Sustainable Land Management" knowledge platform, which simultaneously supports and implements aspects of communication and learning (www.nachhaltiges-landmanagement.de/en/library/ 
documents). The platform also contains a discussion forum. The aim of the platform is primarily to enable the exchange of information and codified knowledge. An online forum is the basis for developing a community of practice $(\mathrm{CoP})$ for all those involved in the funding measure provided by the German Federal Ministry of Education and Research, i.e. scientists, practitioners, representatives from authorities, and so on. The platform enables research results and products to be exchanged, analysed and discussed, also to jointly initiate learning processes for sustainable land management (Weith and Kaiser 2015).

The platform has a graphical user interface. In addition to full-text search, the knowledge base can also be accessed by category-based search. Knowledge resources are differentiated according to products, target group, topics, regions and projects in sustainable land management. On the next level, these five categories are subdivided again into group-specific headings, which also feature selected keywords.

The interactive knowledge platform enabled all registered users to upload their own contributions (texts, images, etc.) between 2013 and 2018. Indexing of the uploaded contributions in the upload area (input mask for uploading contributions) played a major role. Indexing of contributions by the knowledge provider ensures that knowledge stocks can be accessed by category. Category-based access enables knowledge seekers to control the search results. The uploaded contributions were simultaneously made available for discussion in the forum.

In addition to the creation of a knowledge platform, presentations for formalised educational units for higher education were also developed (Weiterbildungsmodule). These units, which focus on a specific topic (e.g. the connection of supply chain management and sustainable land management), are also included in the knowledge platform, besides being specifically disseminated to organisations that deliver vocational training.

In a recent study, Köhler et al. (2019) argue that, in 10 years' time, higher education will resemble augmented human-computer interaction that actively combines educational offers from different educational institutions in a virtual space. In their fourth scenario, entitled "Open educational resources + open science - informal learning using the offers of several universities on the basis of recommender systems", they state that "opening up of the university through digitalisation means that study programs or learning objects from various providers are becoming more and more widespread" when simultaneously "offers from the university are made accessible to external users - which, although technically possible, has barely been implemented." The authors primarily see the following characteristics in this scenario:

- Students' shared knowledge production in a connectivist learning setting;

- Learning objects that are not clearly assigned to a single university, but taken from a virtual information market;

- The implementation of 'trusted repositories' as comprehensive subject-related collections of digital teaching and knowledge objects in the form of OER, OAP, etc. 
As a result, universities may enable the portfolio-based networking of learners, brought together on the basis of suitable portfolios, also when working on interdisciplinary topics, known as "knowledge dating" (ibid.), which leave geographical limitations behind.

\subsection{Discussion and Summary Remarks}

\subsubsection{A Solution? Multifaceted, Networked Digital Knowledge Construction as an Opportunity for Equal Spatial Development}

What options are available for the geographic design of educational spaces? We note tendencies to dissociate the offerings of place and time dependencies, and note tremendous technological advances, which always seem to be one step ahead of the previously proven teaching/learning scenarios. However, if one seeks a creative futurist approach not just in the educational meaning, but also in the spatial planning sense, then we need a new interpretation of geographical/physical space.

In this sense, spatial planning will shift more from functional place-making towards the creation of a virtual network of knowledge co-creators and adopters. This may be easy to imagine using the example of "grassland becomes a land for building maintenance" but, of course, it is harder for us to shift from physical reality to a digital, mediated reality of digital products and environments. As a result, at least two perspectives of knowledge cooperation and digitalisation in the higher education sector for spatial governance can be identified:

1. So far, the integration of different knowledge bases in educational processes has been characterised by information systems and the physical participation of actors (lecturers, students, and to a lesser extent, administrative staff). This is the currently widespread approach of e-learning or online education. However, the practice of education, especially in the higher education sector, is still strongly related to the physical location; regional virtualisation is hardly practiced, if at all. Virtual university cooperation is also neglected. For Saxony, this is evident in the goal of a joint project, initiated only in 2019/2020, focusing on "virtual teaching cooperation" to pilot cross-university teaching networking, taking into account the didactics of collaborative teaching and learning, ideally in a specialist domain and possibly between different types of university. Surprisingly, the newly published coalition agreement of December 2019 states: "Digital forms of teaching and learning as well as open learning materials should find their way into all subjects. We create incentives for this through an innovation fund and drive the digital networking of study programmes. In the long run, the 
Virtual University of Saxony can act as a shared platform." ${ }^{4}$ This could also be regarded as a solution for cooperation with international partners. Furthermore, the subject-independent (interdisciplinary) qualification of educational staff should be promoted to strengthen the effectiveness of the self-regulation of students in online or blended learning scenarios, for example by acquiring online tutoring skills and abilities. Finally, individual Saxony-wide preliminary courses and online self-assessments are supported with the use and creation of OER. $^{5}$

2. In the future, an innovative approach could be the cross-location consideration of partly new forms of generating and disseminating knowledge and learning as a starting point. In this respect, the network-the meaning to be generated in coconstruction-becomes the starting point and replaces the primarily local focus, which is usually only brought together in a few cases afterwards. Area-related co-existence is also practiced, especially in the higher education sector, overcoming the primary location reference. Indeed, examples exist of such common practices of operating and, above all, using digital educational infrastructures. These include the Saxony educational portal ${ }^{6}$ (as mentioned above), the education servers of school administrations, and the nationwide network for open educational resources, represented by OER Info $^{7}$ at the German Institute for Educational Research (DIPF). Obviously, one may find examples of shared developments across individual institutions, leading to new institutional forms.

What are the lessons learned from and opportunities for equal spatial development? As already shown, digitalisation enables especially peripheral and rural areas to participate fully in educational processes. However, this aspiration has only been met to a certain degree as yet because there is no successful interplay of a nationally available, powerful and sustainable digital infrastructure, digital services, and the highest possible degree of innovation. The Digitalization Strategy of the Free State of Saxony calls for the facilitation of a "high quality and attractiveness of a digital offer for all areas of life" (cf. SMWA 2019: 15). It is important to note, however, that uninterrupted broadband access is an urgent requirement that had not been met by 2019, especially in the rural areas of Saxony. In this respect, great hopes are associated with the introduction of the new $5 \mathrm{G}$ standard in mobile communications, which is an essential element of the infrastructure for networked systems, such as required for autonomous driving on roads.

In his recent study on how to apply digitalisation in education in an effort to trigger opportunities for equal spatial development, Schulz (2018) proposes reorganising broadband expansion and related investments in the digital infrastructure in special-purpose (public or municipal) associations. Indeed, he suggests that such

\footnotetext{
${ }^{4}$ https://www.spd-sachsen.de/wp-content/uploads/2019/12/Koalitionsvertrag_2019-2024.pdf (cf. page 16)

5 https://bildungsportal.sachsen.de/portal/parentpage/projekte/hochschulvorhaben/projekte-2019-

2020/virtuelle-lehrkooperationen

${ }^{6}$ https://bildungsportal.sachsen.de

${ }^{7}$ https://open-educational-resources.de
} 
a transformation should also take place in wastewater disposal and public transport. After all, the digital infrastructure, and to some extent water and wastewater disposal and public transport, are not only needed in five years' time, but are now required for today's sustainably planned public services. In this way, a political solution could be created in which public institutions or even the municipalities, serve as stakeholders and act independently or in place of commercial providers. The fact that the federal states and the federal government act as a driving force would certainly support this development, enabling rural communities to move into the digitised future at greater speed.

With regard to the education sector and, detached from the discussion about broadband expansion, Schulz (2018) suggests that the existing physical and digital function and area types in cities and municipalities be recorded and rededicated to new learning, information, knowledge and transfer spaces. These would be interlinked places for education, enriched with digitised offers, whereby no clear assignment is possible or necessary in every case. After all, not only classrooms, public libraries, cafés, city parks, or in fact any public space, as well as workplaces and living rooms at home can be used as places of learning. In this way, learning islands are created which, thanks to their equipment and characteristics, meet learners' individual needs. In a digitised world, the physical offer would feature interfaces, enabling these islands to be integrated and linked to multifaceted ${ }^{8}$ educational spaces that grow together. Reallocations and functional extensions would end the need for a one and only educational infrastructure. The physical location is left behind to enable learning regardless of time and location, with the ideal scenario being a convergence of physical and digital space. Mobile learning already addresses such a media design-but what functions then remain for physical locations?

\subsubsection{Three Assumptions}

Finally, the question of equal spatial development should be asked again. The authors suggest that digitalisation offers considerable opportunities, such as compensating for location disadvantages or developing peripheral regions into attractive places to work and live. Since digitalisation reduces distances to educational offers, this takes place in two directions: a Berlin resident can attend an interesting course online with a provider in Paris, whilst a Parisian can take advantage of an educational provider's offer from Berlin.

With regard to land use and spatial development, governance should reflect actorbased functional interrelations in coupled spaces more broadly. Current scientific discussions have proposed initial options (Newig et al. 2019). To connect spatial planning with the development of higher education systems, the overall framing concept must first be revised as described above. In addition, actors' roles must be

\footnotetext{
${ }^{8}$ The term "multifaceted" is derived from the description of a transformation option for libraries by Eigenbrodt (2014)
} 
redefined. Specialist areas that previously only held advisory roles, as well as civil society, with its needs and independent initiatives, must be involved in the planning process. Bottom-up and top-down actors then form a planning process that takes all aspects into account, contributing to the equal development of educational spaces.

As shown by Köhler and Schilde (2003) and Schulz (2018), many different factors affect the topic of digitalisation, education and space. On the one hand, there are users' behaviours arising from the technical possibilities. These are characterised by individual influences driven by society and peer groups. As associated changes occur in social behaviour, the methodological case of learners and their educational needs also change. Digital components support individuality and are simultaneously becoming increasingly important. Similar to the case of online mail order, the proximity of the offer also plays a largely subordinate role in this case. As the distance from the learner increases, the proportion of digitally depicted elements and processes increases, which is an important point for education providers, be it universities, schools, libraries or private further education companies. However, in the absence of local providers, the competitive situation may be intensified, particularly at local or regional borders. This is shown in exaggerated form in the following three hypotheses:

1. Despite new ICTs, knowledge, control and monitoring functions are spatially concentrated, and routine functions are generally performed decentral (Meusburger et al. 2011).

2. Traditional teaching/learning arrangements will be largely superseded by selfdirected, flexible and individualised forms in the medium term (Köhler et al. 2018, 2019).

3. Physical learning spaces in schools, universities/colleges and vocational education and training institutions will be replaced by digital learning spaces, as learners can access the same resources anywhere, anytime (ibid.).

Obviously, the necessary research would have to address the greater integration of (A) spatial ideas about cooperation in the context of digitalisation and (B) the development of new visions and models based on this, including all domains involving the creation of knowledge and its dissemination into society.

\subsubsection{Methodological Critique and Future Research Needs}

Finally, it is necessary to briefly present a methodological critique of the presented research, and to address the need for future research. Due to the multi-perspectives and the high dynamics of the (socio-)technological development around digitalisation and the variety in its adoption (cf. Fischer 2012), there are certainly inaccuracies in the scientific findings, both in theoretical and methodological terms, which must be discussed briefly in the following. 


\section{Dynamics of the research domain:}

As argued by Meusburger et al. (2011), research has to take into account the historicity of the artefact under investigation. This means that certain elements or configurations are no longer existent, and thus the research object is not always consistent in itself. Due to a learner potentially changing into a teacher or provider of an educational offer via social media channels, open platforms or research networks, it can be assumed that digitalisation will blur the boundaries between decentralised and central functional spaces.

\section{Development and dissemination of new knowledge:}

Overall, the influence of digitalisation on knowledge genesis in the context of sustainable, fair development should not be underestimated-and is relevant for achieving strategic development goals (SDGs; Weith and Köhler 2019). The focus here is on the development and dissemination of new knowledge and the exchange of knowledge (www.futureearth.org). Supporting a transformation towards sustainability is mentioned there as an explicit goal. The associated research agenda states that this also necessitates a new form of knowledge generation across disciplinary boundaries - together with social partners.

\section{References}

Bergner, C. (2019). Improving education through technology in school management. Empirical evidence from schools in Germany. Dresden: Technische Universität.

Bundesministerium für Wirtschaft und Energie (BMWi). (2016). Zukunftschance Digitalisierung. In Gute Geschäfte, zufriedene Kunden, erfolgreicher Mittelstand. Ein Wegweiser (2nd updated ed.). Berlin.

Cash, D. W., Clark, W. C., Alcock, F., Dickson, N. M., Eckley, N., Guston, D. H., et al. (2003). Knowledge systems for sustainable development. PNAS, 100(14), 8086-8091.

Cornell, S., Berkhout, F., Tuinstra, W., Tàbara, J. D., Jäger, J., Chabay, I., \& De Wit, B. (2013). Opening up knowledge systems for better responses to global environmental change. Environmental Science and Policy, 28(C), 60-70.

Davoudi, S. (2015). Planning as practice of knowing. Planning Theory, 14, 316-331.

Dilling, L., \& Lemos, M. C. (2011). Creating usable science: Opportunities and constraints for climate knowledge use and their implications for science policy. Global Environmental Change, $21,680-689$.

Eigenbrodt, O. (2014). Auf dem Weg zur fluiden Bibliothek: Formierung und Konvergenz in integrierten Wissensräumen, S.207-220. In Stang \& Eigenbrodt: Formierungen von Wissensräumen. Optionen des Zugangs zu Information und Bildung. Berlin : de Gruyter Saur.

Enengel, B., Muhar, A., Penker, M., Freyer, B., Drlik, S., \& Ritter, F. (2012). Co-production of knowledge in transdisciplinary doctoral theses on landscape development-An analysis of actor roles and knowledge types in different research phases. Landscape and Urban Planning, 105(12), 106-117.

Erber, G., Köhler, T., Lattemann, C., Preissl, B., \& Rentmeister, J. (2004). Rahmenbedingungen für eine Breitbandoffensive in Deutschland. Berlin: Deutsches Institut für Wirtschaft. 
Fischer, H. (2012). Know Your Types-Konstruktion eines Bezugs zur Analyse der Adoption von E-Learning-Innovation in der Hochschullehre. Dissertation in den Fachgebieten Digital Culture an der Universitetet i Bergen (NO) und Bildungstechnologie an der TU Dresden.

Fromhold-Eisebith, M. (2010). Von der Technologie- zur Wissensregion-Neukonzeption anhand des Beispiels der Region Aachen. In F. Roost (Ed.), Metropolregionen in der Wissensökonomie (pp. 61-81). Detmold: Verlag Dorothea Rohn.

Gibbons, M., Limoges, C., Nowotny, H., Schwartzman, S., Scott, P., \& Trow, M. (1994). The new production of knowledge-The dynamics of science and research in contemporary societies. London: SAGE.

Hesse, F. (2017). Denken und Handeln auf der Basis externen Wissens. Online at: https://www. youtube.com/embed/EsU01gc9bAk?list=PLOw519nehTTxbP9G46-T2O0ppzcLmNQnF\&aut oplay=1. Accessed on June 20, 2020.

Hirsch Hadorn, G., Hoffmann-Riem, H., Biber-Klemm, S., Grossenbacher-Mansuy, W., Joye, D., Pohl, C., \& Zemp, E. (Eds.). (2008). Handbook of transdisciplinary research. Heidelberg: Springer.

Kahnwald, N., \& Köhler, T. (2007). Microlearning in virtual communities of practice? An explorative analysis of changing information behaviour. In: T. Hug, M. Lindner, \& P. A. Bruck (Eds.), Micromedia \& eLearning 2.0: Gaining the Big Picture. Proceedings of Microlearning 06. Innsbruck: University Press.

Kaiser, D. B., Köhler, T., \& Weith, T. (2016). Knowledge management in sustainability research projects: Concepts, effective models, and examples in a multi-stakeholder environment. Journal of Applied Environmental Education \& Communication, 15(1).

Kaiser, D. B., Gaasch, N., \& Weith, Th. (2017). Co-production of knowledge: A conceptual approach for integrative knowledge management in planning. Trans Assoc Eur Schools Plann 1.

Kajikawa, Y., Tacoa, F., \& Yamaguchi, K. (2014). Sustainability science: The changing landscape of sustainability research. Sustainability Science, 9, 431-438.

Köhler, T., \& Kahnwald, N. (2005). Does a class need a teacher? New teaching and learning paradigms for virtual learning communities. In Online Communities and Social Computing. Proceedings of the HCI 2005. New York: Lawrence Erlbaum Associates.

Köhler, T., \& Schilde, P. (2003). From project teams to a virtual organization: The case of the education portal Thuringia. Frontiers of e-Business Research, 2(2).

Köhler, T. (2006). Wissen oder Handeln? Neue Medien aus lerntheoretischer Sicht. In D. Gebert (Ed.), Innovation aus Tradition. Dokumentation der 23. Arbeitstagung des Arbeitskreises der Sprachenzentren, Sprachlehrinstitute und Fremdspracheninstitute (AKS) 2004. Bochum: AKSVerlag.

Köhler, T., Igel, C., \& Wollersheim, H.-W. (2018). Szenarien des technology enhanced learning (TEL) und technology enhanced teaching (TET) in der akademischen Bildung 2028. In: B. Getto, \& M. Kerres (Eds.), Digitalisierung: Motor der Hochschulentwicklung? Münster, Waxmann. https://www.waxmann.com/buch3868. Accessed on June 20, 2020.

Köhler, T., Wollersheim, H.-W., \& Igel, C. (2019). Scenarios of technology enhanced learning (TEL) and technology enhanced teaching (TET) in academic education. A forecast for the next decade and its consequences for teaching staff. In IEEE Proceedings of the 8th International Conference on Learning Technologies and Learning Environments (LTLE2019). Toyama: IAA.

Kujath, H. J., \& Peiker, W. (2014). Wandel des internationalen Städtesystems unter dem Einfluss der Wissensökonomie. Geographische Rundschau, 12(2014), 12-18.

Kujath, H. J. (2010). Institutionen und räumliche Organisation der Wissensökonomie. In H. J. Kujath \& S. Zillmer (Eds.), Räume der Wissensökonomie. Implikationen für das deutsche Städtesystem (pp. 51-81). Berlin: LIT Verlag Dr. W. Hopf.

Lemos, M. C., \& Morehouse, B. J. (2005). The co-production of science and policy in integrated climate assessments. Global Environmental Change, 15, 57-68.

Mauser, W., Klepper, G., Rice, M., Schmalzbauer, B. S., Hackmann, H., Lee-mans, R., \& Moore, H. (2013). Transdisciplinary global change research: The co-creation of knowledge for sustainability. Current Opinion in Environmental Sustainability, 5(3-4), 420-431. 
McLuhan, E. (2008). The source of the term 'Global Village'. In McLuhan studies (Issue 2). https:// projects.chass.utoronto.ca/mcluhan-studies/v1_iss2/1_2art2.htm. Accessed on June 20, 2020.

Meusburger, P., Koch, G., Christmann, G. B., et al. (2011). Nähe- und Distanzpraktiken in der Wissenserzeugung - Zur Notwendigkeit einer kontextbezogenen Analyse. In O. Ibert \& H. J. Kujath (Eds.), Räume in der Wissensarbeit. Zur Funktion von Nähe und Distanz in der Wissensökonomie (pp. 221-249). Wiesbaden: VS Verlag für Sozialwissenschaften.

Millar, C. C. J. M., \& Choi, C. J. (2003). Advertising and knowledge intermediaries: Managing the ethical challenges of intangibles. Journal of Business Ethics, 48, 267-277.

Miller, T. R., Wiek, A., Sarewitz, D., Robinson, J., Olsson, L., Kriebel, D., \& Loorbach, D. (2014). The future of sustainability science: A solutions-oriented research agenda. Sustainability Science, 9, 239-246.

Newig, J., Lenschow, A., Challies, E., Cotta, B., \& Schilling-Vacaflor, A. (2019). What is governance in global telecoupling? Ecology and Society, 24(3), 26. https://doi.org/10.5751/ES-11178240326.

Nonaka, I., \& Takeuchi, H. (1995). The knowledge-creating company: How Japanese companies create the dynamics of information. New York: Oxford University Press.

North, K. (2011). Wissensorientierte Unternehmensführung: Wertschöpfung durch Wissen. 5. Wiesbaden: Gabler Verlag.

Opdam, P., Westerink, J., Vos, C., \& De Vries, B. (2015). The role and evolution of boundary concepts in transdisciplinary landscape planning. Planning Theory \& Practice, 16, 63-78.

Parker, R., \& Hine, D. (2013). The role of knowledge intermediaries in developing firm learning capabilities. European Planning Studies, 22, 1048-1061.

Pohl, C. (2011). What is progress in transdisciplinary research? Futures, 43, 618-626.

Pohl, C., Rist, S., Zimmermann, A., Fry, P., Gurung, G. S., Schneider, F., et al. (2010). Researchers' roles in knowledge co-production: Experience from sustainability research in Kenya, Switzerland, Bolivia and Nepal. Science and Public Policy, 37, 267-281.

Pohl, C. (2014). Eine Theorie transdisziplinärer Forschung für wen? Reaktion auf M.Ukowitz.2014. Auf dem Weg zu einer Theorie transdisziplinärer Forschung. GAIA, 23 (1), 19-22.

Riedel, J., Dubrau, M., Möbius, K., \& Berthold, S. (2017). Digitales lehren \& lernen in der Hochschule. https://nbn-resolving.de/urn:nbn:de:bsz:14-qucosa-217606. Accessed on June 20, 2020.

Salet, W. (2014). The authenticity of spatial planning knowledge. European Planning Studies, 22, 293-305.

Schulz, J. (2018). Digitalisierung in der Bildung. Chancen für eine gleichwertige räumliche Entwicklung? Vortrag auf der LAG-Frühjahrstagung 2018 "Digitalisierung: Der Nordosten ist flach?' Digitale Transformation und gleichwertige räumliche Entwicklung" der Akademie für Raumforschung und Landesplanung (ARL), Landesarbeitsgemeinschaft Berlin/Brandenburg/Mecklenburg-Vorpommern. https://slub.qucosa.de/api/qucosa\%3A2 3393/attachment/ATT-0. Accessed on June 20, 2020.

Semar, W. (2014). Digitale Veränderungsprozesse: Konsequenzen für das Lern- und Kommunikationsverhalten. In O. Eigenbrodt \& R. Stang (Eds.), Formierungen von Wissensräumen. Optionen des Zugangs zu Information und Bildung (pp. 11-21). Berlin/Boston: De Gruyter Saur.

SMWA — Staatsministerium für Wirtschaft, Arbeit und Verkehr. (2019). Sachsen Digital—Digitalisierungsstrategie des Freistaates Sachsen, 3. (Fully revised ed.). Dresden. https://publikationen. sachsen.de/bdb/artikel/33501/documents/51221.

Stang, R., \& Eigenbrodt, O. (2014). Informations- und Wissensräume der Zukunft: Von Hochgefühlen und lernenden Städten. In O. Eigenbrodt \& R. Stang (Eds.), Formierungen von Wissensräumen Optionen des Zugangs zu Information und Bildung (pp. 232-244). Berlin/Boston: De Gruyter Saur.

Stützer, C. M., Köhler, T., Carley, K. M., \& Thiem, G. (2013). "Brokering” behavior in collaborative learning systems. Procedia-Social and Behavioral Sciences, 100. https://doi.org/10.1016/j.sbs pro.2013.10.702. 
Vatn, A. (2005). Institutions and the environment. Cheltenham, UK, Northampton, Massachusetts: Edward Elgar.

Weith, Th., \& Kaiser, D. B. (2015). Wissensmanagement: die Plattform "Nachhaltiges Landmanagement“. In G. Meinel, et al. (Hg.), Flächennutzungsmonitoring VII. Boden - Flächenmanagement - Analysen und Szenarien. Berlin (Rhombos) (pp. 61-66).

Weith, T., \& Köhler, T. (2019). Der Einfluss der Digitalisierung auf die Wissensgenese im Kontext einer nachhaltig-gerechten Entwicklung. Synergie. Fachmagazin für Digitalisierung in der Lehre, Ausgabe \#07. https://www.synergie.uni-hamburg.de. Accessed on June 20, 2020.

Weith, T. (2020). "Smart Countryside" im Osten? Zum Wandel ländlicher Räume und den Herausforderungen der Digitalisierung. In M. Naumann \& S. Becker (Eds.), Regionalentwicklung in Ostdeutschland - Dynamiken, Perspektiven und der Beitrag der Humangeographie. Berlin: Springer.

Ziegler, A. (1993). Wer moderieren will, muß Maß nehmen und Maß geben (Who wants to moderate, has to take the measurements and to provide tailor-made solutions). In A. Wohlgemuth (Ed.), Moderation in Organisationen (Facilitation in organisations) (pp. 17-53). Stuttgart: Haupt.

Zimmermann, K. (2010). Der veränderte Stellenwert von Wissen in der Planung. Raumforschung und Raumordnung, 68, 115-125.

Open Access This chapter is licensed under the terms of the Creative Commons Attribution 4.0 International License (http://creativecommons.org/licenses/by/4.0/), which permits use, sharing, adaptation, distribution and reproduction in any medium or format, as long as you give appropriate credit to the original author(s) and the source, provide a link to the Creative Commons license and indicate if changes were made.

The images or other third party material in this chapter are included in the chapter's Creative Commons license, unless indicated otherwise in a credit line to the material. If material is not included in the chapter's Creative Commons license and your intended use is not permitted by statutory regulation or exceeds the permitted use, you will need to obtain permission directly from the copyright holder. 